


\title{
Tourism Management
}

Special Issue:

The Competitive Destination

Marketing the competitive destination of the future

\author{
C Dr Dimitrios Buhalis
}

\section{Senior Lecturer in Tourism}

University of Westminster

35 Marylebone Road

London, NW1 5LS, England

Tel : +44(0) 1719115000 ext 3112

Fax: +44 (0) 1719115171

Home Tel/Fax: +44 (0) 1483574463

E Mail: buhalid@wmin.ac.uk

Internet: http://www.wmin.ac.uk/Env/UDP/staff/buhalis.htm 


\begin{abstract}
Destination marketing is increasingly becoming extremely competitive worldwide. This paper explains the destination concept and attempts to synthesise several models for strategic marketing and management of destinations. It provides an overview of several techniques widely used and illustrates examples from around the world. The paper also explains that marketing of destinations should balance the strategic objectives of all stakeholders as well the sustainability of local resources. Destinations need to differentiate their products and develop partnerships between the public and private sector locally in order to co-ordinate delivery. Taking advantage of new technologies and the Internet also enables destinations to enhance their competitiveness by increasing their visibility, reducing costs and enhancing local co-operation. Destination marketing must lead to the optimisation of tourism impacts and the achievement of the strategic objectives for all stakeholders.
\end{abstract}




\section{Introducing destinations and destination marketing}

Destination marketing facilitates the achievement of tourism policy, which should be co-ordinated with the regional development strategic plan. Marketing of destinations should also guide the tourism impacts optimisation and the maximisation of benefits for the region. In order to appreciate the complexity of destination marketing this paper explains the destination concept and attempts to synthesise several models for strategic marketing and management of destinations.

The analysis illustrates numerous frameworks for the development of a destination marketing strategy and a comprehensive marketing mix. The paper also illustrates the relationship between marketing and planning of destinations and their conflicting and symbiotic relationship. This paper is based on research and consultancy on destination marketing around the world, where several frameworks have been tested and implemented. It discusses a wide spectrum of destination marketing tools and provides plentiful references for researchers who would like to study in-depth each technique. Although the suggestions and conclusions presented here are inevitably generalised, destinations can use the suggested methodology in order to develop and implement their strategic plan and marketing policies. The contribution of the paper is therefore in synthesising well-developed techniques and to provide a comprehensive framework for destination marketing rather than to introduce original research outcomes.

\section{Destination as an amalgam of tourism services and experiences}

Destinations are amalgams of tourism products, offering an integrated experience to consumers. Traditionally, destinations are regarded as well-defined geographical areas, such as a country, an island or a town. However, it is increasingly recognised that a destination can also a perceptual concept, which can be interpreted subjectively by consumers, depending on their travel itinerary, cultural background, purpose of visit, educational level and past experience. For example, London can be a destination for a German business traveller, whilst Europe may be the destination for a leisure Japanese tourist who packs six European countries in a two week tour. Some travellers will consider a cruise ship to be their destination, while others on the same cruise may perceive the ports visited during the trip as their destination. Often destinations are artificially divided by geographical and political barriers, which fail to take into consideration consumer preferences or tourism industry functions. An example of that is the Alps shared by France, Austria, Switzerland, Italy by often perceived and consumed as part of the same product by skiers. For the purpose of this paper destinations are considered to be a defined geographical region which is understood by its visitors as a unique entity, with a political and legislative framework for tourism marketing and planning. This definition enables Destination Management Organisations (DMOs) to be accountable for the planning and marketing of the region and to have the power and resources to undertake action towards achieving its strategic objectives.

Destinations offer an amalgam of tourism products and services, which are consumed under the brand name of the destination. Leiper (1995, p.87) explains that destinations are places towards which people travel and where they choose to stay for a while in order to experience certain features or characteristics-a perceived attraction of some sort. Cooper et al (1998) define destinations as the focus of facilities and services designed to meet the needs of the tourists. Most destinations comprise a core of the following components, which can be characterised as the six As framework as illustrated in Table 1. Therefore, a destination can be regarded as a combination (or even as a brand) of all products, services and ultimately experiences provided locally. It also enables us to assess the impact of tourism regionally, as well as manage demand and supply in order to maximise benefits for all stakeholders. 
$>$ Attractions (natural, man-made, artificial, purpose built, heritage, special events)

$>$ Accessibility (entire transportation system comprising of routes, terminals and vehicles)

$>$ Amenities (accommodation and catering facilities, retailing, other tourist services)

$>$ Available packages (pre-arranged packages by intermediaries and principals)

$>$ Activities (all activities available at the destination and what consumers will do during their visit)

$>$ Ancillary services (services used by tourists such as banks, telecommunications, post, newsagents, hospitals, etc)

Although there is plenty of literature on destination planning and development of facilities (Inskeep, 1991 and 1994; Pearce, 1989; Gunn, 1994; Davidson and Maitland, 1997), there are few textbooks examining destination marketing (Heath and Wall, 1992; Goodall and Ashworth, 1988) and even fewer illustrate destinations as an experience-provider for tourists and locals (Ryan, 1997 and 1991a). This is also reflected in the academic literature published in journals and other scientific publications. The inadequacy of destination marketing literature probably illustrates the interest of researchers in the impacts of tourism on destinations. Hence, the management and marketing of destinations is often left to industry people and consultants and it is not frequently discussed in the literature or in academic debates. The competitive nature of destination marketing also prevents involved parties from publishing their strategies and marketing plans. In addition, there is an apparent difference between the marketing and planning tourism literature.

Traditionally marketing concentrates on increasing visitation and treats tourism like any other commodity. This approach fails to recognise the unique needs and limitations of each destination as well as their particular geographical, environmental and socio-cultural characteristics. In contrast, planning literature concentrates more on the impacts of tourism and on limiting tourism development, often ignoring the market dynamics and the requirements of entrepreneurs at the destination and the place of origin (Ryan,1991b; Burns,1999). Ryan (1991b) explains that companies and governments in tourism have applied only part of the marketing mix to tourism, i.e., promotion, with little attention being paid to the other components of marketing. However, if tourism is to survive by generating satisfaction among interacting tourists and hosts, it must adopt societal marketing strategies. This involves carefully monitoring tourist satisfaction levels and using these as part of the criteria for success, rather than increasing numbers of tourists; continually monitoring host reactions to tourists, for host-tourist interaction is an important component of the tourist experience; and being aware that infrastructure development of tourism resort areas has implications for the types of tourists that will be attracted (Ryan, 1991b).

\section{The strategic purpose of destinations and their management and marketing}

Destinations are some of the most difficult entities to manage and market, due to the complexity of the relationships of local stakeholders (Sautter and Leisen,1999). Managing and marketing destinations is also challenging because of the variety of stakeholders involved in the development and production of tourism products. The destination experience is essentially comprised of regions, resources and amalgams of tourism facilities and services, which often do not belong to individuals. Instead they represent a collection of both professional and personal interests of all the people who live and work in the area. Managing often conflicting stakeholders' interests makes controlling and marketing destinations as a whole extremely challenging. Hence, strategies and actions should take into account the wishes of all stakeholders, namely indigenous people, businesses and investors, tourists, tour operators and intermediaries, and interest groups. Perhaps the most difficult problem is ensuring the rational use of zero-priced public goods, such as landscapes, mountains, and the sea for the benefit of all stakeholders and at the same time preserving the resources for future generations. Conflicts can easily develop, especially when some (perhaps greedy) stakeholders exploit resources for short-term benefits. A compromise encompassing all these interests is extremely difficult if not impossible, but is the key to long term success (Buhalis, 1999a; Buhalis and Fletcher,1995; Jamal and Getz,1996; Yuksel et al, 1999; Palmer, and Bejou, 1995). 
And yet tourists perceive the destination as a brand comprising of a collection of suppliers and services. Before visiting they develop an image about destinations as well as a set of expectations based on previous experience, word of mouth, press reports, advertising, and common beliefs (Chon, 1991 and 1992; Baloglu and Brinberg, 1997). During their holiday, they "consume" destinations as a comprehensive experience, without often realising that each element of the product are produced and managed by individual players. Most service providers are small and medium-sized tourism enterprises which have a wide range of strengths and weaknesses whilst are also characterised by their independent nature (Buhalis and Cooper,1998, Cooper and Buhalis, 1992). Tourists' overall experience is composed of numerous small encounters with a variety of tourism principals, such as taxi drivers, hoteliers, waiters, as well as with elements of the local attractions such as museums, theatres, beaches, theme parks etc. Their overall impression develops their image of a destination after their visitation. As a consequence there is much overlapping between strategic marketing of the destination as a whole and of each individual supplier at the region. Hence, the competitiveness of each player is often interrelated and almost indistinguishable from one another.

As consumers increasingly value environmental resources they are prepared to pay for them premium prices (Pigram,1996; Archer,1996; Thomas, 1992; Garrod and Willis, 1992; Laarman, and Gregersen, 1996). Hence, local resources become a central asset for destinations and tourism suppliers and their sustainability a core function of tourism marketing. Middleton and Hawkins (1998,p.8) state that "a marketing perspective is essentially an overall management orientation reflecting corporate attitudes that, in the case of travel and tourism, must balance the interests of shareholders/owners with the long-run environmental interests of a destination and at the same time meet the demands and expectations of customers".

DMOs tend to be part of the local, regional or national government and have political and legislative power as well as the financial means to manage resources rationally and to ensure that all stakeholders can benefit in the long term. Destination management and marketing should act as tools and facilitators to achieve a complex range of strategic objectives, which will ultimately need to satisfy the needs and wants of stakeholders. Four key generic strategic objectives should be addressed by DMOs, as illustrated in Table 2. Figure 1 demonstrates the dynamic wheel of tourism stakeholders. The development and implementation of strategic objectives at destinations depends on relationships between stakeholders and thus the implementation of the key generic strategic objectives illustrated in Table 2 will be determined by the dynamics of the actors on this wheel. Naturally each stakeholder aims to maximise the benefits emerging for themselves. Inevitably, the interests of some stakeholders may be conflicting with others and thus some of the four key strategic objectives may be jeopardised. This is often a result of some stakeholder trying to enhance its benefit at the expense of others. For example a tour operator may try to reduce the prices paid to local suppliers in order to increase its profit margin and remain competitive in the marketplace. It is imperative, therefore, for DMOs to use legislative and management tools during planning and management of destinations in order to ensure that the benefits of tourism activity is shared fairly between all stakeholders and that sustainable practices safeguard the regeneration of resources utilised for the production of tourism (Buhalis,1995; Buhalis and Fletcher,1995; Sautter and Leisen, 1999). Failure to ensure and maintain a balance effectively jeopardises relationships between stakeholders, and threatens the achievement of the strategic objectives and the long term competitiveness and prosperity of destinations.

\section{Table 2: Strategic management and marketing objectives for destinations}

Enhance the long term prosperity of local people

Delight visitors by maximising their satisfaction

Maximise profitability of local enterprises and maximise multiplier effects

$>$ Optimise tourism impacts by ensuring a sustainable balance between economic benefits and socio-cultural and environmental costs 


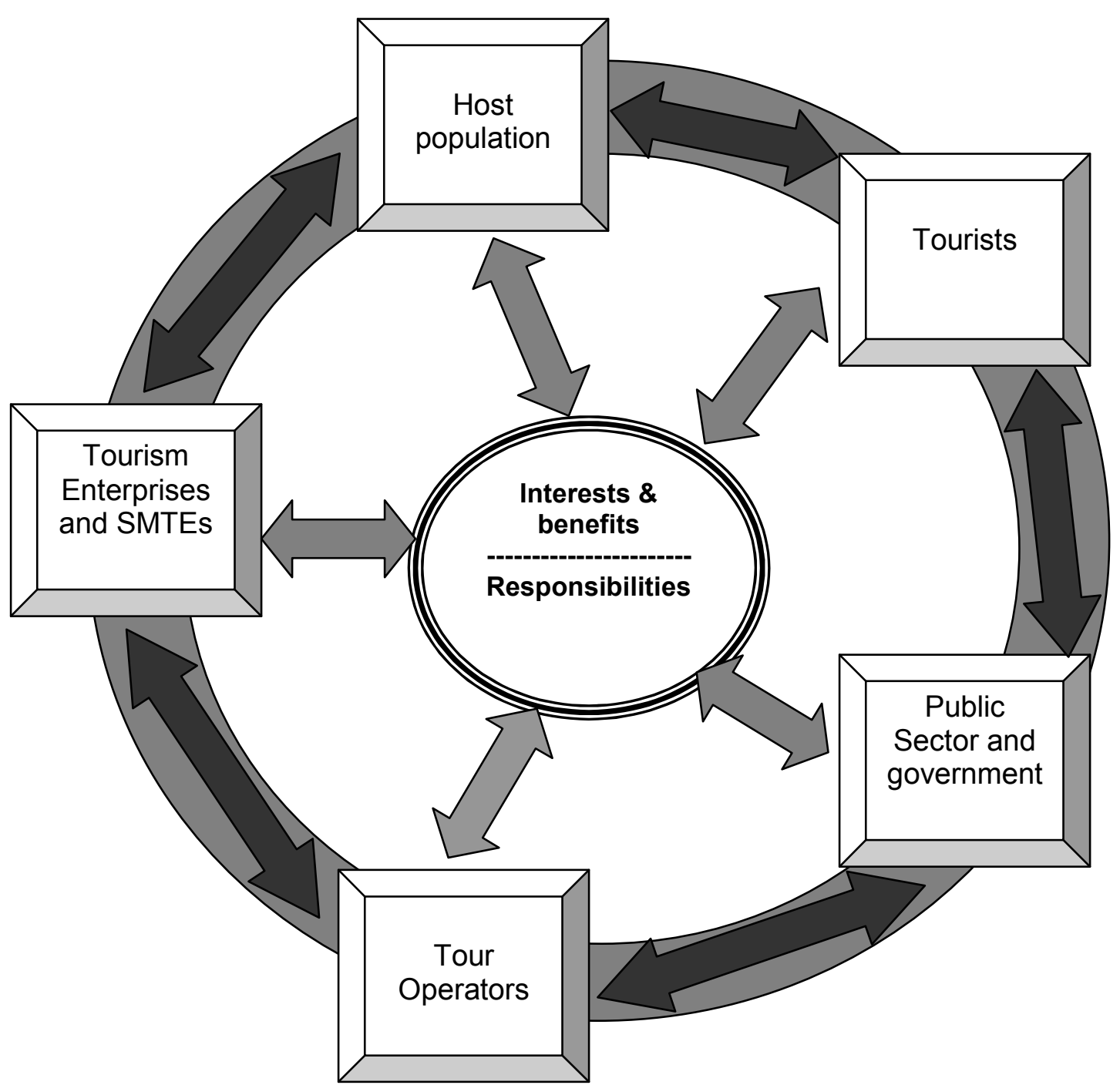

Source: Adapted from Buhalis and Fletcher, 1995.

Hence, tourism marketing should not only be regarded as a tool for attracting more visitors to a region, as it has been the case for most destinations. Instead, tourism marketing should operate as a mechanism to facilitate regional development objectives and to rationalise the provision of tourism in order to ensure that the strategic objectives of destinations are achieved. Tourism marketing should also ensure equitable returns-on-resources-utilised for the production and delivery of tourism products, as well as the regeneration of these resources. It should also provide suitable gains to all stakeholders involved in the tourism system. Hence, marketing should be used as a strategic mechanism in co-ordination with planning and management rather than a sales tool.

Destinations may also involve de-marketing, i.e. the discouragement of certain market segments from visiting the destination during certain periods, through a range of prohibitive measures or by charging premium prices. Examples of these techniques include:

- visitor management techniques in theme parks which divert people from congested attractions to less busy ones by using a leading story/attraction;

- towns like Cambridge, which aims to attract only visitors who stay overnight and to discourage excursionists who contribute little to the local economy by controlling their parking processes;

- Mauritius which provides high quality resort accommodation and does not allow charter flights, therefore promoting high expenditure tourism; or

- Venice, which deters more visitors by charging premium prices for all services offered and recently initiated negative advertisement to reduce mass tourism.

In this way marketing is used as a mechanism to achieve strategic objectives of destination regions and thus, should be guided by the policies for regional development. 


\section{Main markets and destination choice}

Understanding destination types and characteristics is of paramount importance for its marketing. Each destination can only match certain types of demand and hence tourism marketers need to appreciate travel motivations in order to develop appropriate offerings and brand destinations for the right target markets. In addition, destinations should be aware not only of the needs and wants of the active demand but also of the potential markets they can attract. It can then develop a product portfolio, which will enable the optimisation of benefits and adapt their marketing mix to their target markets (McKercher,1995, Tribe,1997). Consumer behaviour studies indicate that a wide range of criteria is used to select tourism products. These criteria are altered according to the purpose and features of the trip, elements of the external environment, the characteristics of the traveller and the particularities and attributes of destinations. Several analysts have examined tourism consumer behaviour in detail (Gilbert, 1991 and 1993; Swarbrooke and Horner, 1999; Goodall, 1988 and 1991; Kent,1991; Mansfeld,1995; Mayo and Jarvis, 1981; Sirakaya et al, 1996; Mazanec, 1989; Mazanec, and Zins, 1994; Moutinho, 1987, Ryan, 1997, Woodside, and Lysonski, 1989).

Classifying travel behavior and segmentation becomes increasingly more difficult as modern travelers combine pleasure with business, in order to take time and cost advantage. There are therefore endless variations between the two principle classifications of travel activities, i.e. business and leisure trips. However, leisure trips may include elements, characteristics and motivations of business travel and vice versa. Incentive travelling, extended conference stays and business meetings during leisure travel makes the distinction between the two categories increasingly blurred. Nevertheless the two principle categories are fairly identifiable and they are treated differently in this text for simplifying the concepts and marketing responses.

Business trips are fairly inflexible and it is often difficult for travelers to select their destinations. Business travel, often referred to as MICE (Meetings-Incentives-Conferences-Exhibitions), is normally determined by business opportunities and involvement of the traveler with organisations at the destination. Perhaps more flexibility can be exercised by travelers attending optional meetings, which provide benefits but are not strictly essential to their business such as conferences, exhibitions, incentives, familiarization trips etc (Davidson 1994). Even though business tourism is much more restricted in terms of choice, destinations providing a high degree of efficiency and safety, as well as elegance and leisure opportunities tend to be preferred for conferences and incentive travel. Business travel is seasonal, as people do not generally travel less during the holiday seasons, i.e. summer months and public holidays. Nevertheless, business tourism provide much higher revenue for enterprises as consumers are willing to pay more for their inflexible schedules and also destinations can increase their multiplier effects as some particular forms of business tourism use a much greater spectrum of local services than leisure tourism. Convenient transportation connections with major cities around the world, smooth arrangements at the destination and adequate provision of business related amenities are therefore very important. Urban destinations in developed countries with strong economic activity and vibrant markets tend to receive the majority of business traffic, as a result of the business meetings taking place locally. The location of meeting partners, host organisations, as well as company policy may determine the selection of destinations for business travel. In addition, corporate rates, membership of loyalty clubs (i.e. frequent flyer or frequent guest) as well as the availability of service providers are some additional criteria used to identify suitable destinations and service providers for the MICE market (O’Brien,1998, BTA,1999;Vlitos-Rowe, 1994).

Leisure travelers, on the other hand, use a much more complex set of criteria in selecting their destination. They have a much higher price elasticity and therefore, price is a key element in the decision making process (Gilbert, 1991 and 1993; Swarbrooke and Horner, 1999; Goodall, 1988 and 1991; Mayo and Jarvis, 1981). In addition, leisure travelers are often time sensitive as families with children cannot travel during school time, creating the seasonality problem for the industry. However, different market segments have dissimilar seasonality patterns. For example, pensioners and elderly people tend to travel during the low season to benefit from discounts, whilst Scandinavian tourists tend to stay home during the summer months in order to enjoy the whether. School children and 
University students go on field research trips or excursions during the low season. Therefore, destinations have to identify the seasonality patterns of their various markets and attract compatible segments, which will enable them to maximise their total yield (both average expenditure and occupancy levels) (O'Brien, 1996). It is also important to understand other factors that influence the decision of consumers to purchase. The social status and peer groups of consumers often influence what is acceptable and desirable as a destination. Travel intermediaries also play a significant role in determining the destination decision of consumers by using a wide range of promotional techniques and often channeling travelers to destinations and principals who offer higher remuneration for them. This will also enable destinations to manage their resources according and attract the right market segments in order to optimize their impacts.

Nevertheless for both leisure and business markets, perhaps the most important criterion for selecting to visit or not to visit a destination is its image. Image is the set of expectations and perceptions a prospective traveler has of a destination. Past experience of the destination or the companies involved (i.e. airlines, hotels, tour operators); descriptions by friends and relatives; general information; and marketing campaigns develop these expectations and perception which may be true or imaginary representations. (Baloglu and Brinberg, 1997; Chon,1991 and 1992; Chacko, 1997). Interestingly, the sustainability of local resources becomes one of the most important elements of destination image, as a growing section of the market is not prepared to tolerate over-developed tourism destinations and diverts to more environmentally advanced regions. The degree of consumer satisfaction will depend on the assessment of the perceived overall experience of the destination versus anticipated expectations and perceptions. Developing the right image for destinations will therefore determine their ability to satisfy visitors as it will allow them to develop realistic and fulfil-able expectations (Morgan and Pritchard, 1998; Seaton,1997;Pearce,1997).

\section{Types of destinations, target markets and marketing strategies required}

Developing a destination typology is a difficult task, as different visitors use destinations for different purposes. Nevertheless most destinations can be classified in several categories which represent their principle attractiveness, as illustrated in Table 3. Understanding and appreciating the type of destination enables marketers to develop a suitable destination marketing mixes and deliver them to the appropriate target markets.

Urban destinations have been involved in tourism since the early years of the civilisation. People used to travel to cities and towns to meet politicians and business associates. Sports organisations, such as the Olympic Games in ancient Greece also generated tourism activity in main cities. People also travelled to cities on pilgrimage for religious purposes, as this is where all major cathedrals, mosques and temples were usually located. Urban destinations have also been attracting business travellers attending meetings, conferences and exhibitions. Most urban destinations are well equipped with conference and exhibition halls and transportation and accommodation infrastructure to facilitate the organisation of larger events. Urban destinations also attract leisure travellers, especially during periods of low business travelling activity, such as weekends and school holidays. Suppliers and facilities aim to reduce seasonality by developing the number of leisure visitors, despite the fact that they can only charge a fraction of the price they charge business travellers. On the other hand, leisure travellers can take advantage of some of the unique facilities and services of urban destinations to enjoy short-breaks or extended weekends. London for example provides a wide range of heritage attractions as well as a wide range of entertainment opportunities such as theatre, concerts, bars, theme restaurants, discos etc. Barcelona offers excellent conference facilities, combined with a culturally interesting and relaxed atmosphere. New York is highly regarded for shopping, sight seeing and theatre going. Urban destinations also attract education and health tourists, as they are generally equipped with good educational establishments and hospitals. Increasingly urban resorts take advantage of their industrial heritage and use obsolete industrial sites as educational experiences and leisure facilities. The Docklands in Liverpool and coal mines in Skipton are good examples of these facilities (Berg, et al, 1995, Law, 1996, and 1993, Page, 1994; Mazanec, 1997). 
Table 3: Types of destinations-Main target markets and activities undertaken

\begin{tabular}{|l|l|l|}
\hline $\begin{array}{l}\text { Type } \\
\text { Destination }\end{array}$ & Customers & Activities \\
\hline \multirow{3}{*}{ Urban } & Business-MICE & $\begin{array}{l}\text { Meetings-Incentives-Conference-Exhibitions } \\
\text { Education-Religion-Health }\end{array}$ \\
\cline { 2 - 3 } & Leisure & Sightseeing-Shopping-Shows-Short breaks \\
\hline \multirow{2}{*}{ Seaside } & Business-MICE & Meetings-Incentives-Conference-Exhibitions \\
\cline { 2 - 3 } & Leisure & Sea-Sun-Sand-Sex-Sports \\
\hline \multirow{2}{*}{ Rural } & Business-MICE & Meetings-Incentives-Conference-Exhibitions \\
\cline { 2 - 3 } & Leisure & Ski-Mountain Sports-Health- \\
\hline \multirow{2}{*}{$\begin{array}{l}\text { Authentic } \\
\text { Third World }\end{array}$} & Business-MICE & Meetings-Incentives-Conference-Exhibitions \\
\cline { 2 - 3 } $\begin{array}{l}\text { Unique-Exotic- } \\
\text { Exclusive }\end{array}$ & Leisure & Relaxation-Agriculture-Learning activities-Sports \\
\cline { 2 - 3 } & Lusiness-MICE & Exploring business opportunities-Incentives \\
\cline { 2 - 3 } & Lusiness-MICE & Adventure-Authentic-Charities-Special interest \\
\hline
\end{tabular}

Seaside destinations and resorts traditionally serve tourists on holidays. Travellers from Northern regions and climates tend to spend a proportion of their annual holiday in the South where they can enjoy sunshine as well as sea sports. Seaside resorts nearby the place of residence were replaced by international destinations as a result of the emergence of mass tourism since the 1970s. For example, in the UK traditional resorts such Blackpool, Scarborough, Bournemouth and Brighton were replaced by the Spanish Costas through the development of package holidays. Typically European leisure travellers will take their annual holiday at Mediterranean seaside resorts, whilst Northern Americans visit Southern regions such as Florida, California and the Caribbean. As the product in traditional seaside resorts matures, new long haul and exotic destinations, often in less developed countries attract sophisticated travellers who are looking for authentic and off-the-track experiences. The globalisation experienced reduces distances and enables people to travel further afield. Examples include destinations such as Goa and Bali which take advantage of developments in transportation and attract travellers. Examples of seaside destinations and resorts can be identified globally (see for example Jenner, and Smith, 1993; Gayle and Goodrich, 1993; Lockhart and Drakakis-Smith, 1997; Morgan,1995; Briguglio, Archer, et al, 1996; Brigulio, Butler, et al, 1996; Shaw and Williams, 1997; Conlin, and Baum, 1995; Towner and Newton, 1996).

Alpine destinations attract leisure travellers for winter sports, such as skiing, as well as holidaymakers who appreciate natural attractions in all seasons. They also attract activity holidaymakers such as naturalists, mountain cyclists, walkers etc. Although the majority of alpine sports are for recreational purposes a wide range of expeditions and challenges are organised for mountains such as the Everest or the Alps. Lakes may also offer facilities for sea sports such as surfing and skiing. Although the majority of alpine resorts are in near proximity to urban centres and thus can easily be accessed by private car, several are still unexplored and offer authentic experiences for travellers. Lakes and scenic landscapes make alpine resorts increasingly more popular for conference and incentive tourists and thus a certain business travelling activity can be observed in the last few years. The development of important business, political and economic meetings, such as the Davos Forum, attract a new market segment and expand the season for winter resorts. As a result a wide range of marketing and planning implications emerge to allow alpine areas to benefit from tourism and yet to ensure the sustainability of their resources (Johnston and Edwards, 1994; Weiermair, 1993; Khan, 1994).

Rural tourism is also developing rapidly. Farmers and rural populations take advantage of the desire of travellers to go back to nature and experience some authentic agricultural processes. Hence agricultural facilities are often transformed to leisure activities. Tourism is regarded as a development tool for several regions where their agriculture declines steadily or where people would like to diversify their living and working patterns. Tourists can stay in rural areas and contribute to agricultural activities taking place or assume a more passive role. There is an 
educational element to this activity particularly for children from urban centres who may have never experience agricultural life. Rural tourism can also be themed according to the activities undertaken, such as cooking or bee-keeping schools organised in rural regions. Examples of this form of tourism can be identified globally (Page and Getz, 1997, Sharpley and Sharpley, 1997 Oppermann, 1996).

Destinations in authentic (often Third World) countries are often off the beaten track. Tourists enjoy authentic experiences in places which have experienced limited tourism development. Emerging destinations in Asia, South America and Africa attract a small number of adventurous tourists who are prepared to forego their comfort in order to interact with local communities and unspoiled surroundings. Although these regions may develop at a later stage to mass tourism destinations, they need to be planned properly in order to sustain their resources. They often lack the required infrastructure to deliver tourism services (Silver,1993; Hughes, 1995; Sofield, 1991).

Finally certain destinations are branded unique-exotic-exclusive as they are regarded to offer a unique and precious experience. As a result, these destinations are promoted as "one-in-a-lifetime" experience and they are promoted premium prices. Examples include Bhutan, Mauritius, and Seychelles. In some destinations, there are several mechanisms controlling the number of visitors, often through managing their transportation and accommodating capacity or immigration procedures and visa allowances. These destinations focus on the non-charter and non-mass traveller reducing their visitation but maximising their income per visitor. They often epitomise the dream of the average traveller and thus are packaged and priced as prestigious products, for instance for weddings, honeymoons, anniversaries or a special occasion trip, or for incentive travel.

\section{Marketing research: identifying market segments for destination products}

Marketing research is used extensively by destination marketers to identify the types of customers that can be attracted (active demand), as well as the prospective visitors (suppressed demand) who do not visit for a variety of reasons (Athiyaman, 1997). Approaching the right target market and providing the most appropriate combination of local tourism products and services is the secret for successful destinations. Product design and formulation should therefore be based on research (Baker et al, 1994; Ritchie, 1996, Calantone and Mazanec, 1991;Hu and Ritchie,1993). As tourism bundles are formulated ad-hoc to satisfy specific consumer requests, a dynamic marketing research process will enable destinations to provide unique products by initiating local partnerships between all suppliers to address the needs of demand. Destination image is also developed through marketing research, which guides promotional activities towards branding and amending the brand values of the region. The effectiveness of promotional campaigns can be assessed so that the most cost-effective media is used to approach and persuade target markets to visit the destination (Woodside, 1990). Table 4 illustrates the contribution of marketing research to destination marketing.

\section{Table 4: Contribution of marketing research to destination marketing}

Identification of the main attributes anticipated by each market segment

Design and attributes required for tourism products and services

Evaluation and development of destination image

$>$ Segmentation of market and development of corresponding marketing mixes

$>$ Opening new markets and reducing dependency on existing ones

$>$ Evaluation of the elasticity of demand for each market segment

$>$ Reduction of seasonality by matching market segments

$>$ Examination of reasons deterring people (suppressed demand) from visiting destinations

$>$ Assessment of compatibility with other target markets

$>$ Examination of alternative distribution channels

$>$ Assessment of tourism impacts to the destination and selecting the right segments

$>$ Evaluation of marketing effectiveness and selection of media for promotion 
Marketing research should not be limited to before visitation investigations. As tourism demand is extremely dynamic, marketing research needs to follow constant developments to ensure that all elements of the destination marketing mix evolve continuously. Surveys during and after visitation enable destinations to identify weaknesses and concentrate their corrective action. Data is often collected by frontier controls, airports and transport authorities, national statistics offices, local councils, tax offices as well as principals such as hotels, travel agencies etc. The effectiveness of marketing research in destinations will depend on their ability to co-ordinate the research activities undertaken by the entire range of local authorities and organisations. It is therefore very important to co-ordinate all these surveys and data in order to produce meaningful inferences to inform and guide tourism policy and marketing strategies (March, 1994; Hawes et al, 1991).

\section{Marketing destinations: strategies and practices}

Developing a marketing strategy and mix for destinations is a complex process, mainly because there are many independent stakeholders and principals involved. Destinations cannot be managed or marketed as enterprises, due to the dynamics of interests and benefits sought by stakeholders. In addition, most destinations are amalgams of independent SMTEs, which already follow their own marketing strategies. Although DMOs have traditionally taken marketing responsibility for the destination product, they fail to control marketing activities and mixes of individual players and hence can only co-ordinate and guide, rather than undertake a comprehensive marketing strategy. Perhaps the most important challenge for destination marketing therefore is to bring all individual partners together to compete rather than to co-operate and to pool resources towards developing an integrated marketing mix and delivery system (Buhalis and Cooper,1998; Fayos-Sola, 1996).

The international tourist industry is becoming an increasingly competitive marketplace where only the best-managed destinations are likely to prosper. Comprehensive strategic business plans therefore need to address all factors that have an impact on the product. Tourism strategies should not only concentrate on visitation, but also include the entire range of impacts such as overcrowding, environmental problems, visitor safety and security, seasonality problems, and sensitivity to local culture (Evans, et al 1995). This will enable destinations to develop comprehensive strategies to fulfil all strategic objectives illustrated in Table 2.

\subsection{The position of destinations and their marketing}

Perhaps one additional complication to tourism marketing is that in most cases destinations have already a rich history and legacy development which needs to be taken into consideration when developing tourism marketing strategies. Not only consumers develop certain images and views about places, but also previous development often provides several limits for marketing to address as well as stakeholders who need to be respected and consulted. Understanding therefore the stage and roots of tourism development is critical for development a strategy. One of the most widely used tools for undertaking this task is the destination life cycle (Butler, 1980). The main utility of the destination life cycle is to facilitate the understanding the evolution of tourist products and destinations and it to provide guidance for strategic decision taking. Cooper (1989, 1992 and 1994) suggests that the life cycle concept illustrates that destinations experience a "birth to death" cycle and that the life cycle model has gained attention in tourism and hospitality as an explanatory tool. Although in tourism life cycle analysis is often seen as a useful conceptualisation tool for destination area development, in hospitality management it is beginning to be used as a guide for strategic planning. However the main problems relate to identifying turning points, stages, length of stages and level of aggregation. Despite the many criticisms of the life cycle concept, it is quite critical for marketers to appreciate the stage of development of resort areas (Haywood, 1986). A number of researchers have used the cycle as a framework for analysing changing destinations 
(Agarwal, 1997; Shaw and Williams,1997; Formica and Uysal, 1996; Tooman, 1997; Douglas, 1997; Choy, 1992; Getz, 1992; Ahmed and Krohn,1990; Cooper and Jackson, 1989).

Based on the above literature, Figure 2 synthesises the different stages destinations are going through during their life cycle and illustrates how that effects their tourism impacts. This also illustrates that different stages of the life cycle require different marketing strategies and planning actions. This is largely due to the differences between demand and supply experienced at different levels. In the early stages demand exceeds supply whilst this relationship is reversed in the maturity and consolidation stages. As a result, marketing strategies should focus on building awareness and promoting the destination product on the early stages of the circle while they probably have to deal with image alteration and re-design and re-launch the product at the later stages. The entire marketing mix therefore will need to be differentiated to accommodate the needs of destinations at each stage of their life cycle. In addition, Figure 2 highlights that destinations experience different environmental and socio-cultural impacts during the different faces. As a result they need to use marketing to encourage sustainable practices for both consumers and industry as well as to communicate their environmental and socio-cultural policies. 
Figure 2: Destination life cycle and tourism impacts

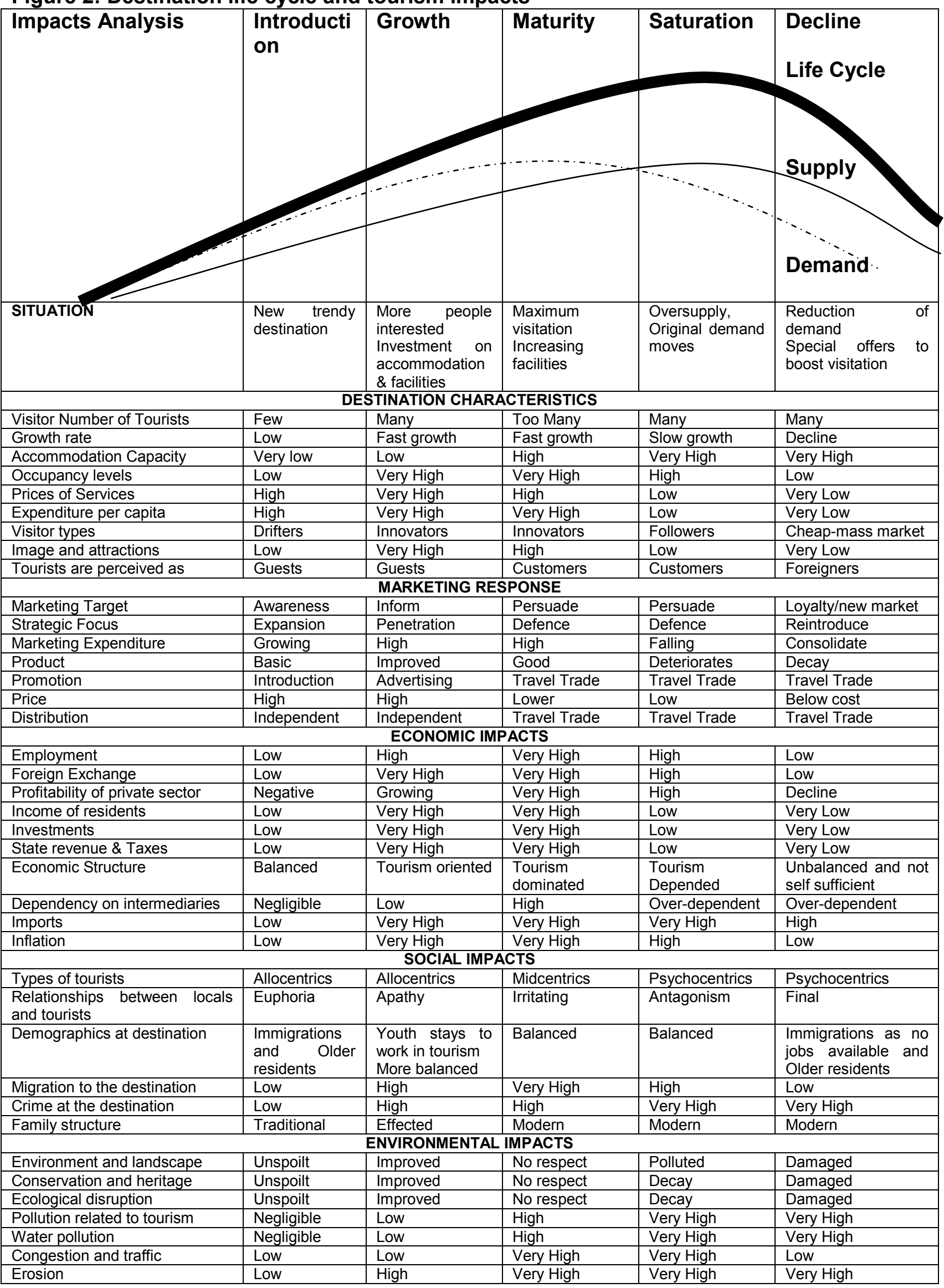

It is evident, therefore, that different destinations are affected in a dissimilar pattern on each stage of their life cycle and as a consequence they require specific marketing action. For example Northern European coastal resorts have experienced declining visitor numbers and decay which 
has resulted to alteration of main use of facilities as well as a concentration on few expanding markets (e.g. senior citizens, conferences and language schools). In contrast, the majority of coastal regions in Southern Europe face a decline of tourism benefits, rather than numbers of visitors as a result of their progression from one stage of the cycle to the next one. Paradoxically in most cases the number of visitors increase mainly due to the price reductions used to stimulate demand. Established mass tourism destinations, such as Benidorm, use a high volume low profit margin strategy to ensure their profitability and they are successful in increasing their visitors. However unless carefully managed any increase of visitors deteriorates local resources further and pushes destinations in greater decline, which forces to further price reductions and further quality decrease. This is a vicious circle which eventually makes the purpose and benefit of the entire tourism activity at the destination questionable. Clearly therefore resorts will need to take into consideration the phase of development there are in as well as the patterns of destination life cycle experienced in competing destinations and adopt their strategic marketing accordingly.

\subsection{Strategic marketing for destinations and strengthening their competitiveness}

Competitive strategy "is the search for a favourable competitive position in an industry". This is a function of both the attractiveness of the industry and the relative competitive position within that particular industry, as well as alternative activities that an organisation can undertake. "Competitive strategy aims to establish a profitable and sustainable position against the forces that determine industry competition" (Porter,1985). Competitiveness is, therefore, defined here as the effort and achievement of long term profitability, above the average of the particular industry within which they operate as well as above alternative investment opportunities in other industries. This definition includes therefore the concept of opportunity cost and illustrates that successful organisations should not only compete within their particular industry but also against other investment opportunities. When referring to tourism destinations competitiveness should also include the sustainability of local resources for ensuring the maintenance of long term success as well as the achievement of equitable returns-on-resources utilised to satisfy all stakeholders.

There is little written about the competitiveness of tourism destinations. Bordas (1994a and 1994b) has developed several frameworks which determine destination competitiveness. They are based on demand and supply as well as a wide range of factors influenced by the external environment of the destination. Ritchie and Crouch (1993) have developed a comprehensive model for tourism organisations, as illustrated in Figure 3 , which can be analysed further to include the entire range of factors affecting the competitiveness of destinations.

Figure 3: Ritchie and Crouch model for tourism destination competitiveness

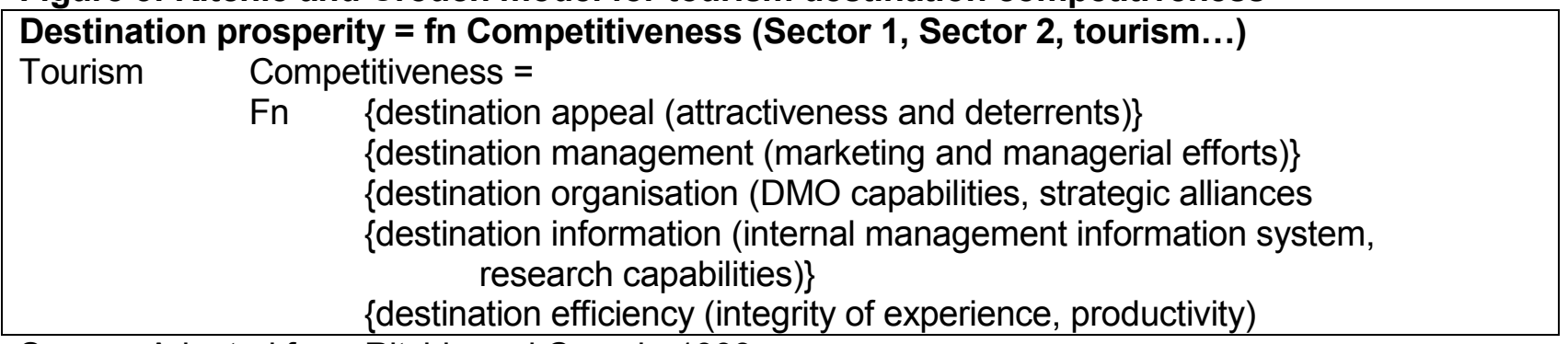

Source: Adapted from Ritchie and Crouch, 1993.

The framework explains that the prosperity of destination depends on the competitiveness of all economic sectors as well as the competitiveness of tourism. A further analysis illustrates the competitiveness of tourism is a function of several factors related to destination administration. A wide range of elements are included in the model illustrating that tourism is affected by an endless number of factors in its internal and external environment. Although the model fails to rate the importance of each of the elements examined, it is suggested that a dissimilar rating should be adopted by different destinations depending on the types of markets they attract, their life cycle stage and specific characteristics. Nevertheless the contribution of the Ritchie and Crouch lies on the comprehensiveness and wideness of the elements taken into consideration. The model also highlights that it is the combination of all factors comprising the competitiveness of destinations as 
well as synergies between these elements that determine the attractiveness of a region. Perhaps future research will attach ratings to each factor for specific types of destination and also illustrate potential tradeoffs that consumers may consider. Consumers may be willing to compromise some elements for some others, for example overcrowdness for cheaper price in some Spanish Costas. Understanding the values and prime aims would be critical for developing the module further. Ultimately the competitiveness of destinations depends on their ability to maximise their performance for each individual element assessed.

\subsection{Strategy formulation for destinations}

This paper reviews three strategy models, namely Porter's generic strategies, Gilbert's proposition for "differentiation of the destination" and Poon's analysis for "flexible specialisation". The paper then synthesises their propositions in order to propose a generic strategy and illustrate how destinations should develop their offerings.

\subsubsection{Porter's generic strategies}

Figure 4 illustrates the three main strategies proposed by Porter (1980) aimed to "outperform other firms in an industry", i.e.:

$>$ Overall cost leadership, where organisations are required to minimise their costs, based on mass production and strict cost control of the main business functions;

$>$ differentiation of products or services offered by "creating something that is perceived industrywide as being unique";

$>$ focus on a "particular buyer group, segment of the product line or geographical market" and achieve either cost leadership or product differentiation.

Figure 4 Porter's three generic strategies

\begin{tabular}{|c|c|c|c|}
\hline \multirow{2}{*}{\multicolumn{2}{|c|}{ 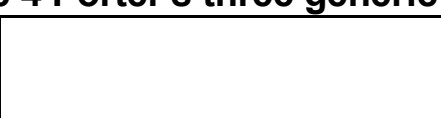 }} & \multicolumn{2}{|c|}{ STRATEGIC ADVANTAGE } \\
\hline & & Perceived product uniqueness & Cost advantage \\
\hline \multirow{2}{*}{$\begin{array}{l}\text { TARGET } \\
\text { MARKET }\end{array}$} & $\begin{array}{l}\text { Industry } \\
\text { wide }\end{array}$ & - Differentiation & - Cost Leadership \\
\hline & $\begin{array}{l}\text { Particular } \\
\text { segments } \\
\text { only }\end{array}$ & - Differentiation Focus & - Cost Focus \\
\hline
\end{tabular}

Source: Adapted from Porter, 1980, p.39.

This is well-developed generic model, which is widely used to all industries. It provides clear guidance for decision makers to position their products in order to maximise profitability and improve their competitiveness. However, this model fails to address the specific needs of tourism and in particular the scarcity of resources at the destination level. Therefore, similarly with commodities this model suggests unlimited resources are available to reproduce endless number of products. This is particularly the case for the cost leadership strategy where organisations are urged to increase their volume and to reduce their profit margin. Unfortunately environmental resources, both natural (e.g. coral reefs or mountain landscapes) and man-made (e.g. archaeological sites or architectural structures) have a limited capacity which they can accommodate. Resources in tourism are irreplaceable once destroyed and therefore a strategy should ensure that their use is limited to the degree that does not threat their sustainability in the long term. Once this is understood and appreciated, Porter's model enables tourism marketers to focus on differentiation strategies and to develop their mix accordingly. However, several destinations, which are on the consolidation phase of their life cycle, have exceeded the maximum capacity which would have enabled them to sustain their resources. Their ability to promote differentiated tourism products has also been jeopardised, as over-development has exploited and damaged their resources. This is experienced in some mass tourism destinations, such as Benidorm and Costa Brava in Spain, or Faliraki and Malia in Greece. 
Once destinations have reached that stage there is limited choice. The majority try to attract more mass tourism so they can increase their profitability through volume. Increasingly however some regions aim to renovate their properties and facilities and re-launch their offerings. The Calvia example in Mallorca, which decided to demolish three hotels in order to improve public areas and to enhance the quality of its products set new best practices which may be followed by other regions.

\subsubsection{Gilbert's strategic framework}

Based on the above rational the second strategic framework introduced by Gilbert (1984 and 1990b) argues that destinations can classified on a continuum between a "status" and a "commodity" area, as illustrated in Figure 5.. "Status areas" achieve intentional demand as a result of the unique product attributes perceived by the tourism market. These unique attributes may be genuine or imaginative and thus, a destination is regarded as irreplaceable, which increases consumers' loyalty and willingness to pay. In the "commodity status" case, destinations are substitutable, very sensitive to price and economic changes, while consumers have a low awareness of any unique benefits or attributes. Thus, travellers base their decision to visit the area merely on price, while the demand for the destination is incidental and destinations are unable to attract high spenders. Despite the fact that the sustainability of resources is not discussed explicitly by the model, it is quite evident that "status areas" manage their resources as product attributes and therefore are appreciated by consumers who are willing to pay more.

Figure 5: Gilbert's differentiation strategy

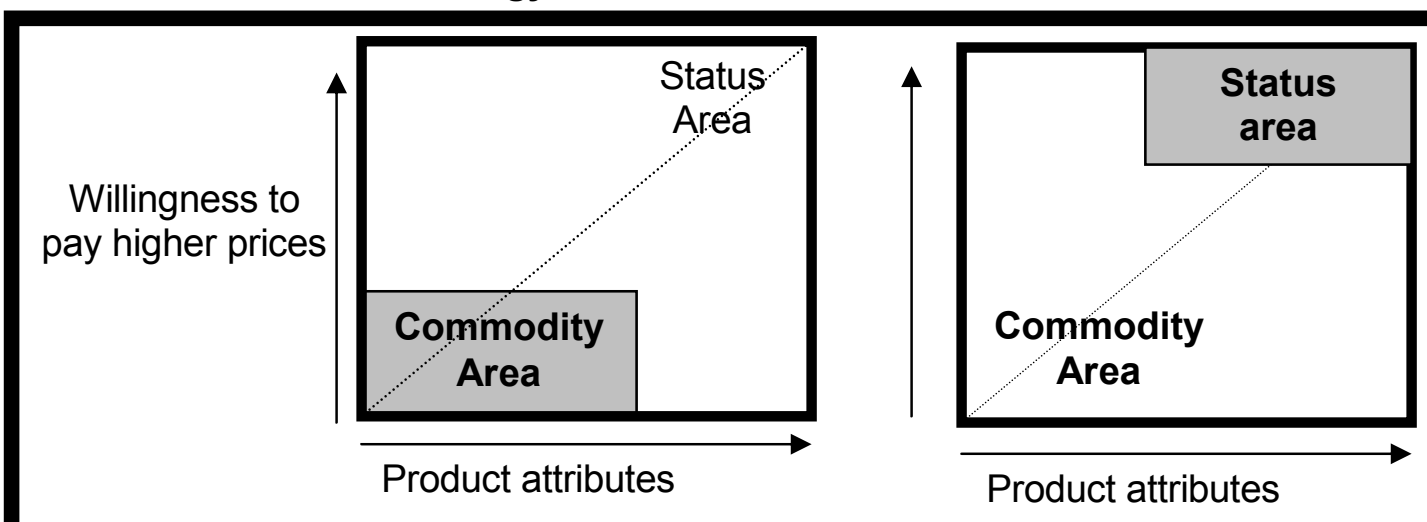

Source: Adapted from Gilbert, 1990, p.25

Gilbert (1990) asserts that destinations should attempt to become "status areas", rather than a "commodity area" one, in order to improve their image, loyalty and economic benefits. It is suggested that destinations should differentiate their tourism products in order to achieve a unique "tourist product benefit". This will enable them to establish their position in the international market, and attract both high spenders and loyal tourists, who appreciate the uniqueness of their resources and offerings. Although the model clearly differentiates destinations to distinctive categories it fails to recognise that the majority of destinations lay between the two ends of the continuum. It also fails to relate to the different stages of the life cycle and to the inevitability experienced in several regions where destinations are launched as status areas and gradually slip to commodity status (Buhalis,1999a). Nevertheless the model clearly contributes to tourism marketing by correlating product attributes with willingness to pay and also by illustrating clearly that destinations should decide on what direction they should plan and manage their resources and facilities.

\subsubsection{Poon's flexible specialisation}

A third strategic approach for tourism is proposed by Poon (1989 and 1993), based on the concept of "flexible specialisation" of the tourism business. Poon examines the tourism industry processes and proposes a strategy to enable tourism organisations to improve their competitiveness. Poon argues that "flexible specialisation" is a strategy of "permanent innovation" and "ceaseless change" which provides for "new tourism". New tourism is flexible, segmented, customised to the tourist's needs and diagonally integrated. In contrast, old tourism can be characterised as "mass, standardised and 
rigidly packaged". "The main sources of flexibility for service firms lie in the organisation, management, marketing, distribution and other forms of interaction and interrelationships among guests, hotels, suppliers, distributors. What is important however is not each of these stand-alone aspects but how they are coupled to create competitive advantages and hence, capabilities to move with the market" (Poon, 1993). This is a timely model, which predicted the impact of information technology on the both decision making and consumer behaviour. Industry innovation is critical in this strategy and the utilisation of new technology provides the opportunity to customise products according to customers' specific requirements. Hence destinations can organise their assets and attributes in such a way which will enable them to specialise their tourism product according to particular demand needs.

Although Poon's model revolutionised tourism thinking it is still difficult to implement at the destination level. The majority of infrastructure and superstructure is based on fixed assets, which cannot be altered easily and therefore they have a limited degree of flexibility. This is more evident at destinations at the consolidation stages, which are unable to reinvent themselves and approach new markets. Nevertheless, the model clearly contributes to the field by encouraging tourism organisations and destinations to challenge existing strategies and practices and to forcing them to approach new tourism with new tools introduced by technology. Concentrating on core functions and outsourcing all peripheral activities to networks of virtual co-operations should enable destinations and enterprises to innovate and to adapt to the needs of consumers constantly.

\subsubsection{Synthesis of strategic frameworks and lessons for strategic destination marketing}

The discussion of the three models provides several interesting lessons. A close examination of strategies reveals that they share a similar base. Porter's "differentiation", Gilbert's "status area" and Poon's "flexible specialisation" describe how firms and destinations can achieve value competitive advantages. Consumers appreciate special attributes and values and as a result they are inclined to visit areas more regularly, to increase their loyalty and to pay higher prices. In contrast, "cost leadership", "commodity area" and "standardisation or the "Fordism production model" describe the efforts of firms or destinations to achieve "cost competitive advantage" by offering their products for less than their competitors. This is achieved through economies of scale, standardisation and mass production. Destinations and tourism products are treated as commodities and decisions are merely based on price. Hence the underlying concept of the two alternative strategies is the relationship between volume and price. The first set of strategies supports a "low volume-high profit margin" approach, where each consumer is paying premium prices for unique products, whilst the second set of strategies follows a "high volume-low profit margin" approach.

Tourism destinations should avoid the cost advantage strategies as they are based on mass production and consumption and assume unlimited production capacity and resources. The inseparability of the tourism product determines that consumers should be present at the time of product delivery. Therefore, the interaction of consumers with socio-cultural and environmental scarce resources can decay the very reasons, which attract people to places. Seasonality also generates demand peaks and inflates the problem during certain periods every year. Although economic benefits can also be achieved by using the "commodity area" or the "standard product model", it is argued that on the long term these approaches reduce tourist satisfaction, consumer willingness to pay, and are against demand trends. In addition, the "high volume-low profit margins" strategy has catastrophic social and environmental impacts on destinations. As a result, not only their sustainability may be jeopardised but also the competitiveness of the region as a whole. Effectively these strategies push destinations through their life cycle stages and force them to reach their consolidation stage. Destinations therefore should define and not exceed their carrying capacities in order to sustain their resources and at the same avoid jeopardising consumers satisfaction.

This is reflected on both Gilbert and Poon's strategies which agree that destinations should aim to achieve a "status area" or "niche" orientation through differentiation, in order to increase consumer satisfaction as well as to maximise the benefits for tourism regions. This strategy is already adopted in several resort areas, such as Valencia in Spain, where it is recognised that the need for diversification and differentiation "has now become essential owing to the level of competitiveness 
that has been attained (and can be foreseen) in the world tourist market" (Fayos-Sola, 1992). It is also particularly useful for insular, peripheral and remote destinations, where a limited number of economic and financial resources are available. However, this strategy should not serve as an excuse for principals at destinations for not improving their efficiency and minimising their production costs. Although providing unique service to satisfy tourist needs should be their priority, offering perceived value for money would determine their competitiveness in the marketplace (Murphy and Pritchard, 1997). As most destinations consist of networks of tourism suppliers and principals, there is much overlapping between the strategic orientation followed at the macro and micro level. Hence a close collaboration between the private and public sector is required. Destinations and enterprises following a "status area" strategy would probably enhance tourists' satisfaction, as well as their competitiveness. The formulation of unique and customised products by using flexibility and cooperation will also increase tourists' willingness to pay and their loyalty, while responding to new tourism demand trends.

Unfortunately, some destinations can no longer be positioned as irreplaceable unique products, due to over-development and degradation of their resources. Tourism supply has exceeded their carrying capacity and they have reached the saturation or decline phases of their life cycle. For example several Mediterranean "costas" have been overdeveloped to such an extent that only a high-volume, low-profit margin orientation is feasible. When resorts reach their saturation level only a "cost leadership" or "mass production" strategy can be employed, as they are unable to provide any specific "tourist product benefit". The attraction of the lower end of the market is inevitable and as a consequence, there are no alternative strategies. In this case the minimisation of further social and environmental damages as well as attempts to improve the surrounding environment should also be the primary objective.

In addition, a re-positioning of the product can also be attempted although it is quite difficult to alter the image of destinations. For example the Calvia Municipality in Mallorca has implemented a dynamic plan for enhancing the quality of the tourism offering through the enhancement of the landscape and the regeneration of environmental resources. As a result, intentional demand has increased and a higher willingness to pay is experienced, increasing the profitability of the private sector and boosting the economic impacts of tourism. Another successful example of destination management and marketing is also Las Vegas. Although it has not yet on the maturity level, the local industry constantly undertakes initiatives to reinvent and reposition itself. They diversified their target markets by developing theme parks within major hotels in order to attract families and young children. Several new hotels open every year while older properties are being renovated, often by demolishing properties and rebuilding them. The "old strip" was also relaunched to attract visitors from the new hotels and casinos.

\section{Destination marketing mix}

Once a tourism management and marketing strategy has been decided destinations will have to develop their marketing mix. This will enable them to approach each target market with a comprehensive range of offerings and to propose an integrated solution to consumer needs and wants. Developing a marketing mix for destinations will depend on each destination, the types of target markets and a whole range of issues on the external environment. Nevertheless some principles need to be addressed and the following text illustrates examples and frameworks which can assist destination marketers to decide on the most appropriate marketing mixes.

\subsection{Formulating the destination product}

Destinations are amalgams of individually produced tourism amenities and services (accommodation, transportation, catering, entertainment etc) and a wide range of public goods (such as landscape, scenery, sea, lakes, socio-cultural surroundings, atmosphere etc). All these elements are branded together under the name of the destination. The ubiquity of the destination concept effectively means that the tourism product for each prospective traveller is very subjective and depends heavily on his/her image and expectations of the place. Nevertheless, the tourism product for a region consists of the entire range of facilities and services offered locally, plus all 
socio-cultural, environmental resources and public goods. Understanding the core product as well as the facilitating, supportive and augmented products for each target market is of paramount importance for destination marketing. The augmented environment will include intangible elements such as interaction and customer participation as well as accessibility and physical environment (Kotler et al,1996,p.276)

DMOs have an overall responsibility for the entire destination product and through incentives and policies facilitate the development of products, which is desirable from the demand side, and at the same time does not jeopardise local resources. DMOs should therefore be the guardians of the image and resources of destinations. However, throughout the world tourism services are offered by small and medium tourism enterprises (SMTEs) which tend to be family managed. The challenge for destination management organisations is therefore to provide leadership in the development of innovative products and create local partnerships for the delivery of seamless experiences. These partnerships should bring together both private and public sector and should ensure that the long term competitiveness of the tourism product prevails all decision making processes (Buhalis and Cooper,1998).

DMOs also need to enhance and differentiate their products by emphasising their uniqueness. Destination marketers often adopt a mass tourism orientation, because they falsely believe that tourism products can grow indefinitely. Hence, generic characteristics of destinations are frequently emphasised in all marketing campaigns as they attempt to attract too many target markets. Sun and sea dominate the promotion of Mediterranean destinations; exotic surroundings are emphasised for long haul destinations and skiing is offered by Alpine resorts. However, it is increasingly evident that new-sophisticated consumers seek authentic and unique experiences. They are also willing to pay a premium, but only if the product is significantly better than that of competitors. Hence, destinations will need to re-assess the entire range of their resources and identify suitable tourism products for each particular target market segment.

Themed or alternative tourism enables destinations to provide unique experiences. For example, Greece could concentrate on its heritage and history and offer ancient/mythology experiences; Italy can develop culture/art/design/fashion/cuisine themes; Romania should explore the Dracula myth; and Bali should concentrate on the unique religious rituals and cultural traditions. Natural, agricultural, cultural, artistic, heritage, resources of destinations can be used accordingly. Tourism should also contribute to the preservation of these resources by increasing the awareness of both locals and visitors and by providing funds for the conservation and regeneration of resources. Attracting appropriate target market segments should also assist the reduction of seasonality, as special theme offerings, as well as festivals and events should enable destinations to increase their demand during the low season. For example, the renovation of physical features and natural resources on Mallorca, or the development of innovative new products such as Festivals and themed experiences (e.g. Edinburgh New Year's Eve and summer festivals) also enable destinations to manage their product life cycle effectively. The aim is to maintain the destination to the maturity/consolidation stages and to avoid the stagnation, saturation and decline stages in their life cycle.

\subsection{Pricing the destination}

A wide range of pricing techniques are applicable to tourism destinations (Meidan, 1995; Kotler et al,1996). However, pricing is a difficult process for destinations as it is often determined by the pricing and marketing policies of individual enterprises both at the destination and distributors at the place of origin. Local suppliers can have their own policy and thus co-ordinating and establishing a destination wide pricing strategy is almost unachievable. Furthermore, national economic policies and economic conditions in the international marketplace also influence pricing. Therefore, both macro- and micro- economics determine the pricing function of tourism organisations locally and destinations. The cost of living and employment, as well as inflation, exchange rates and local efficiency and competition all contribute to the pricing equation. Tourism in Japan is inevitably much more expensive than tourism in Indonesia due to the differences between the two economies. Macroeconomic changes have great influence on the pricing of 
destination and the attraction of consumers. For instance, the depreciation of the Spanish Peseta and the Greek Drachma as well as the high inflation rate of the Turkish Lira have all determined the pricing of their destinations and have influenced their competitiveness (Edwards, 1993).

Pricing the destination and all the individual elements of the local tourism product is a very complex process. Principals tend to have their own pricing mix and policies. DMOs can control elements of pricing through regulation, advice and through partnerships with the private sector. However, DMOs often provide guidelines by suggesting minimum prices to protect small suppliers from fierce competition and maximum prices to protect consumers from overcharging. For example, in several destinations the public sector determines the lowest price per category for accommodation, advises on the retail price of consumer goods and foods, set the maximum prices for transportation or taxi services. Although enforcing pricing policies is extremely difficult, destination managers should formulate partnerships with principals and train them on the importance of maintaining a fairly standardised pricing structure and policy.

In several leisure destinations tour operators also play a critical role in determining the price consumers pay for products locally. This is has significant implications for destinations which depend on intermediaries (tour operators) for their clientele, and in particular for destinations which have an oversupply of facilities. Tour operators in Europe and especially the larger/mass/integrated operators, such as Airtours, Thomson, TUI, and Neckerman, exercise bargaining and coercive power because of the large volume of tourists they represent and reduce the prices of principals at destinations. This enables them to offer competitively priced products at their marketplace. However, as local suppliers may not be able to gain enough profit from the basic product (i.e. accommodation and transfers) they may need to overprice other element of the product (i.e. catering, entertainment, local excursions) in order to boost their profitability (Buhalis, 1999b).

The higher the expenditure of tourists locally the better it is for destinations, as it increases the profitability of local enterprises and enhances the economic benefits. Consumers take into consideration the total cost of a trip, i.e. before, during and after their visit. In most cases they have not visited the destination before they purchase their travel product. Hence pricing plays an important role in determining the image of destinations. Perhaps the biggest travel expenditure is transport to and from the destination, especially for long haul trips, and thus can determine the willingness and ability of travellers to visit destinations.

Destinations can only charge premium prices if they offer a unique experience. Venice for example profits from its unique product attributes and charges substantially higher prices than other Italian destinations. However, increasingly consumers are unimpressed by tourism facilities and products, as they have travelled extensively and have acquired a wealth of experiences. Global competition and oversupply, as well as the emergence of new destinations in third world countries with lower labour costs, generate frequent price wars especially for constrained capacity at the last minute. As a result, consumer are increasingly prepared to pay less for getting more. Nevertheless, it is important for consumers to perceive prices as fair and good value for money, because dissatisfaction damages the competitiveness of the destination.

\subsection{Distributing tourism destinations}

Distribution or marketing channels are defined as sets of interdependent organisations involved in the process of making a product or service available for use or consumption. The ultimate objective of distribution channel can be summarised as: delivering the right quality and quantity of a product, in the right place, at the right time, at the right cost, to the right customer. Several important distribution and marketing functions performed by channel members, such as: carrying of inventory; demand generation through promotion; market information collection and analysis; negotiation between channel members and consumers; physical possession and distribution; risk taking; payment and financial arrangements; and after-sale service. Distribution is emerging as a critical element of strategic management and as one of the few remaining sources of real competitive advantage. Apart from influencing costs, increasingly distribution channels also support and enable product differentiation by 
adding value on the product and by contributing to the total brand experience and projecting powerful images

The entire range of players that bring together tourism demand and supply for a region formulate its distribution channel. Distribution of destinations becomes increasingly more important, not only because it is estimate to cost $20-30 \%$ of the product price but also because it determines whether and under what conditions suppliers can meet their target markets. This is the case especially in the European leisure market context as concentration has led four major companies to dominate the market. Business travellers have strict schedules and use intermediaries to organise their itineraries. In contrast, leisure travellers tend to have much greater flexibility and price elasticity. As a consequence, intermediaries can influence their decision and choice of destination.

Business travellers can be influenced indirectly by people who are responsible for arranging business meetings and conferences. These include corporate travel officers and administrative staff in organisations who choose the location of meetings, as well as services suppliers. For destinations to attract business travellers they need to develop strong links with the local business and academic communities as well as with various types of associations. This will enable DMOs to appreciate the needs of business travellers and to provide convenient and adequate products. Often local associations, chambers, businesses or academics need to be closely involved in order to attract and arrange Meetings, Incentives, Conferences, and Exhibitions (MICE) at the destination. Consequently, relationships with business travel agencies as well as conference and exhibition organisers are important to attract and satisfy the MICE markets.

Leisure travellers have a much wider choice and flexibility and therefore a different distribution strategy and mix are required. Domestic tourists usually make direct arrangements and often use their own transport, whereas international leisure travellers tend to be more influenced by intermediaries. Representation of destinations in tour operators' brochures determines their ability to attract the appropriate volume and quality of consumers. Leisure travellers often require travel agencies advice on selecting appropriate destinations and products. Hence, destinations need to provide travel agencies with information and promotional material, as well as to organise educational trips and provide incentives for their staff in order to promote the destination to consumers. Workshops and road shows may also increase awareness and provide positive impressions. Travel trade manuals serve as reference books for intermediaries offering comprehensive information about destination regions. Developing long-term partnerships with tour operators and leisure travel agencies is therefore extremely significant for the success of leisure destinations.

The concentration of the European tourism industry increases the power of certain integrated travel organisations. As a result, they increasingly control more than $70 \%$ of the market and can use a wide range of marketing techniques to determine consumer choice. Table 5 illustrates the penetration of the largest tour operating groups in the European market and clearly demonstrates that leisure movement in Europe is directed to a large extent by a small number of integrated tour operators (O'Brien, 1996; Bywater 1992 and 1997). Since then more concentration is experienced daily as operators merge to develop their volume and take advantage from economies of scale and negotiation power. In addition, a wide range of smaller specialised tour operators exists in each market promoting specialised products.

Table 5: Penetration of the largest tour operator groups in the European leisure market in 1994/5

\begin{tabular}{|l|l|r|}
\hline Country & Tour Operators & Estimated market share \\
\hline United Kingdom & Thomson/Airtours/First Choice & $58 \%$ \\
\hline Belgium & NUR (Neckerman) & $50 \%$ \\
\hline Austria & Touropa/ITAS/Ruefa/Kuoni/Neckerman & $45 \%$ \\
\hline Scandinavia & Airtours (Spies, Tjaereborg) & $43 \%$ \\
\hline Ireland & Budget/JWT (First Choice) & $40 \%$ \\
\hline Germany & TUI/NUR/LTT & $37 \%$ \\
\hline Netherlands & TUI (Holland International/Arke) & $30 \%$ \\
\hline
\end{tabular}


\begin{tabular}{l|l} 
France & Nouvelles Frontières/Club Med
\end{tabular}

Source: Adapted from O'Brien, 1996 and Bywater, 1997 and 1992

Although, there is a concentration on leisure distribution channels, consumers become more independent and sophisticated and use the entire range of tools to arrange their travel. The availability of information on the Internet and the emergence of electronic intermediaries revolutionise distribution. Destinations that appreciate the new developments and build comprehensive tools for their local suppliers increasingly improve their ability to reach their strategic objectives. IT enables consumers to seek for information as well as construct and purchase individual itineraries on-line, and thus it revolutionised destination marketing. Not only do they provide opportunities for reducing dependency on traditional intermediaries for remote, peripheral and insular destinations but they also provide a mechanism to develop and promote specialised products for mini market segments (Buhalis, 1998).

Electronic distribution also offers opportunities for closer interaction and co-operation at the local level. In several places where IT has been used extensively, such as Tyrol, Ireland and Singapore, an integration of local resources and organisations enables suppliers at the destination level to develop and deliver seamless tourism products to consumers. Destination Management Systems will need to be developed in order to enable the networking of all local tourism providers as well as a comprehensive and innovative interface between the destinations and their prospective and current clients (Buhalis, 1994 and 1997).

\subsection{Promoting the destination}

Promoting destinations essentially implies the development of communicating channels with clientele and other stakeholders to increase awareness and persuade to purchase products. Destination promotion requires a co-ordinated campaign and message for all local principals and suppliers. Designing a cost-effective promotional mix is difficult because of the diversity of tourism suppliers at destinations and the spread of consumers throughout the world. Achieving a consensus on the marketing campaign as well as raising adequate funds to develop and implement it is one of the most challenging tasks for destination marketing. Traditionally, DMOs lead promotional campaigns, whilst suppliers participate and contribute. A wide range of techniques are used, both above and below the line (Kotler, et al,1996; Horner and Swarbooke,1996).

Above the line promotional activity includes advertising on television, radio, and press as well as using poster campaigns. Targeting the right market with the right message at the right time is always difficult, especially for destinations, which attract consumers from several geographical regions as well as cultural and linguistic backgrounds. Although very expensive, above the line advertisement can assist the development of the destination brand as well as influence a large number to visitors to travel to the destination or to extend their visit (Bonham and Mak,1996). Crouch (1994) has illustrated that although many countries have substantially increased their spending on tourism promotions there is little evidence of their effectiveness as studies which have attempted to evaluate the promotional impact empirically have generally produced inconclusive and varied results. Nevertheless, DMOs are increasingly being held accountable for generating adequate results through advertising and for measuring advertising effectiveness (Woodside, 1990; Faulkner,1997; Crompton, 1997; Schoenbachler et al, 1995). Advertisements use slogans, which change frequently in order to follow tourism demand trends and to update the image of destinations (Morgan and Pritchard, 1998). For example, Spain recently changed its slogan from "everything under the sun" to "passion for life". This change reflected the refocus of its product away from the traditional "sun and sea" product to a much more sophisticated offering based on socio-cultural diversity and the life-style of local people (Fayos-Sola,1996).

In addition, DMOs often use below the line promotional techniques. They participate in major annual tourism and travel fairs in Berlin, London, Milan, Madrid, Paris and elsewhere. There they have the opportunity to meet intermediaries and members of the public to promote their offerings. They produce brochures, which they distribute to all their partners in the industry and to 
prospective consumers who require information on the destination. Brochures normally show local attractions and activities, whilst they also feature a number of local suppliers such as hotels, entertainment and catering establishments (Wicks and Schuett, 1991, 1993). In addition, travel trade manuals offer information about the destination to the travel trade and provide a reference guide.

Although DMOs often operate information offices where they provide information about local suppliers they tend to refrain from selling direct, as they regard themselves as facilitators rather than intermediaries and also avoid to be seen as promoters of individual products and services against other local suppliers. Instead, when asked by prospective customers they provide contact details of local suppliers and advise consumers on the ones that are likely to satisfy their demand. However, increasingly DMOs are forced to play a more active selling role as consumers appreciate an one-stop-service. In many destinations they are also required to justify their income or to contribute towards their expenses and hence they charge commissions for local bookings and sell maps, local guidebooks and souvenirs to generate income. Direct marketing is also used as destinations can identify prospective customers and promote elements of the local offerings that satisfy the specific demand. Developing relationship marketing and loyalty clubs enables repeat visitors to be recognised and appreciated. Discount schemes and other add-ones are currently developing for several destinations to reward and maintain their loyal clientele.

Finally, public relations are extensively used for most tourism destinations. Destination representatives at national level establish tourism offices in their major markets to distribute promotional material and information as well as through their embassies. In addition, public relations are used to generate news stories, articles and publicity in order to develop the awareness of consumers and persuade them to purchase the products. Often hosting a journalist or a celebrity in the destination can generate more interest than any other forms of promotion because consumers are more passive receivers than with advertising. Public relations are also critical for the development and updating of the right image (Morgan and Pritchard, 1998; Kotler et al,1996; Middleton,1992).

\section{Marketing competitive destinations for the future}

Destination marketing is increasingly becoming extremely competitive worldwide. Providing innovative and well co-ordinated tourism products is therefore exceedingly important for tourism regions. Consumers assess their travel experience as a whole and they associate destinations with the entire range of local producers and suppliers. Producing innovative and specialised tourism products will enable destinations to attract intentional demand and to differentiate their products. Flexible specialisation will also support local suppliers and the region as a whole to evolve with consumer trends and support the requirements of the emerging sophisticated clientele as well as compete globally. Destinations, which appreciate these principles, can develop and maintain competitive advantage and as a result achieve their strategic objectives.

Partnerships between the public and private sector and close co-operation between all local suppliers is key to the ability of destinations to offer quality products. Exceeding consumers' expectations is therefore instrumental for the ability of both suppliers and destinations to attract visitors in the long term. Hence the competitiveness of each supplier locally as well as their distributors determines the competitiveness of destinations. Local suppliers should co-operate rather than compete. Buhalis and Cooper (1998) argue that tourism suppliers at destinations need to mature and understand that they should not compete with each other at the destination level. Instead they should join forces and pool resources to develop and implement comprehensive marketing strategies which enable them to compete with other destinations. The rapid development of new destinations, especially in third world countries generates an unprecedented level of competition. They can offer unspoiled natural landscapes and authentic socio-cultural resources inexpensively. In contrast, most traditional destinations suffer from their own success and the lack of a strict rational planning and management system. Having gone through most of the stages of they life cycle they have reached maturity or saturation and this has forced them to rely mass tourism for their operations. Often facilities require urgent renovation, but lack of financial 
resources and the unwillingness of consumers to pay jeopardise the competitiveness of destinations further. Initiatives at the local level facilitated by both private and public sectors can improve the tourism product by investment in resources, as well as the implementation of a comprehensive marketing strategy and mix which supports the competitiveness of the destination. This is particularly important for the small and medium tourism enterprises, which traditionally dominate local supply but lack management and marketing expertise to operate their business professionally and financial resources to approach their target markets.

Taking advantage of new technologies and the Internet can also enable destinations to enhance their competitiveness. Technology can improve the efficiency of all local suppliers and also provide tools for the development and delivery of differentiated tourism products. Provision of information on local facilities and attractions and the ability to reserve the whole range of tourism products determines the ability to attract the new and sophisticated types of tourism demand. The recent evolution of Destination Management Systems (DMSs) enables destinations to co-ordinate the entire range of products and services offered locally and to promote them globally. The provision of differentiated and tailor made products becomes much easier as consumers can assemble specialised products and construct their own itinerary. The availability of information on local resources and services reduces the cost of individual travel and enables destinations to offer mass-customised services.

More importantly the new IT tools enable even smaller and peripheral players to compete at equal footage with larger and more central ones and therefore provide an unprecedented opportunity to enhance their competitiveness. One of the major benefits is the reduction of dependency on intermediaries for the distribution of tourism products. As a consequence, tourism suppliers are able to improve their negotiation power with powerful tour operators and can develop a healthier distribution mix. This is particularly significant for remote, peripheral and insular destinations where local principals and authorities have a great dependency on tourism for their lifehood but lack expertise and resources to undertake comprehensive marketing campaigns. Partnerships marketing through loyalty/fun clubs enabling destinations to develop long-term relationships with consumers benefit both destinations and suppliers. DMSs should also be utilised to optimise tourism impacts by providing an effective mechanism to bridge the expectations of both consumers and local residents with their experiences from tourism (Buhalis, 1993, 1994, 1997)

Finally tourism destinations should learn from past mistakes and appreciate that their strategic management and marketing must lead to the optimisation of tourism impacts and the achievement of their strategic objectives for all stakeholders. Hitherto, destinations have suffered because they wrongly assumed that the higher the volume of tourists, the more benefits they can achieve. However it is evident that limits on the development of tourism activity should be imposed in order to avoid over-exploitation of local resources. Although marketing has often been regarded as an enemy of sustainability, destination authorities and principals need to realise that strategic marketing should be used to achieve destination policies. A comprehensive marketing strategy should enable managers and planers to identify appropriate target markets and to maximise economic benefits locally without jeopardising local resources. A suitable communication strategy should support destination authorities to convey their message and promote environmentally friendly practices locally.

In conclusion, destination marketing is becoming more complex as tourists consume regions as experiences, often ignoring that tourism products consist of a great number of individually produced products and services. Global competition and industry concentration develop new challenges. In this sense, destination marketers have to achieve the strategic objectives set through stakeholders' analysis and match the appropriate demand with supply, by using the entire range of marketing tools for communicating with consumers and suppliers. Global competition and the new, experienced, demanding and sophisticated travellers reposition destination marketing to be the main interface between consumers and local principals. Consumers are increasingly following special interests and regard their trips as both recreational and educational experiences. Therefore, destination themes and their interpretation become more important for the future. Training of human resources as well as co-operation between competing and complementary 
destinations enable regions to learn from each other and adapt to demand requirements. Innovative marketing led by research and using new technologies, will be the only way to manage and market competitive destinations in the future for the benefits of their stakeholders.

\section{REFERENCES}

Agarwal, S. 1997; The resort cycle and seaside tourism: an assessment of its applicability and validity, Tourism Management, Vol.18(2), pp.65-73.

Ahmed, Z. U., Krohn, F. B., 1990, Reversing the United States declining competitiveness in the marketing of international tourism: a perspective on future policy, Journal of Travel Research, Vol.29(2), pp.23-29.

Archer, B., 1996, Sustainable tourism-Do economists really care?, Progress in Tourism and Hospitality Research, Vol.2(3\&4),pp.217-222.

Athiyaman, A., 1997, Knowledge development in tourism: tourism demand research, Tourism Management, Vol.18(4),pp.221-228.

Baker, K. G., Hozier, G. C., Jr., Rogers, R. D., 1994, Marketing research theory and methodology and the tourism industry: a nontechnical discussion, Journal of Travel Research, Vol. 32(3), pp3-7.

Baloglu, S., Brinberg, D., 1997, Affective images of tourism destinations, Journal of Travel Research, Vol.35(4), pp.11-15.

Berg, L. van den, Borg, J. van der, Meer, J. van der, 1995, Urban Tourism: performance and strategies in eight European cities, Avebury, Aldershot.

Bonham, C., Mak, J., 1996, Private versus public financing of state destination promotion, Journal of Travel Research, Vol.35(2), pp.3-10.

Bordas, E. 1994a, Competitiveness of tourist destinations in long distance markets, Revue de Tourisme, Vol.49(3),pp.3-9.

Bordas, M., 1994b, Competitiveness of tourist destinations in Long distance markets, Etudes et Memoires, Centre des Hautes Etudes Touristiques, Aix-en-Provence.

Briguglio, L., Archer, B., Jafari, J., Wall, G., 1996, (eds) Sustainable tourism in islands and small states: issues and policies, Pinter, London.

Briguglio, L., Butler, R., Harrison, D., Filho, W.L., 1996, (eds) Sustainable tourism in islands and small States: Case studies, Pinter, London.

BTA, 1999, Business Tourism Leads the way, A report by the Business Tourism Forum and the Business Tourism Advisory Committee, January, British Tourism Authority, London.

Buhalis, D., 1993, Regional Integrated Computer Information Reservation Management Systems as a strategic tool for the small and medium tourism enterprises, Tourism Management, Vol. 14(5), pp.366-378.

Buhalis, D., 1994, Information and Telecommunications Technologies as a strategic tool for small and medium tourism enterprises in the contemporary business environment, in Seaton, A., et al (Eds), Tourism-The State of the Art: The Strathclyde Symposium, Wiley and Sons, England, pp.254-275.

Buhalis, D., 1995, The impact of information telecommunication technologies on tourism channels: implications for the small and medium sized tourism enterprises, PhD Thesis, University of Surrey, Guildford, UK.

Buhalis, D., 1997, Information and Telecommunication Technology as a strategic tool for economic, social and environmental benefits enhancement of tourism at destination regions, Progress in Tourism and Hospitality Research, Vol.3(1), p.71-93.

Buhalis, D., 1998, Strategic use of information technologies in the tourism industry, Tourism Management, Vol.19(5), pp.409-421.

Buhalis, D., 1999a, Limits of tourism development in peripheral destinations: problems and challenges, Tourism Management, Vol.20(2), pp.183-185.

Buhalis, D., 1999b, Relationships in the distribution channel of tourism: Conflicts between hoteliers and tour operators in the Mediterranean region, Journal of International Hospitality, Leisure and Tourism Administration, Vol.2(2) (forthcoming).

Buhalis, D., and Cooper, C., 1998, Competition or co-operation: The needs of Small and Medium sized Tourism Enterprises at a destination level, in E., Laws, Faulkner, B., and Moscardo, G., (ed.), Embracing and managing change in Tourism, Routledge, London. 
Buhalis, D., and Fletcher, J., 1995, Environmental impacts on tourism destinations: An economic analysis, in Coccosis, H., and Nijkamp, P., (eds), Sustainable Tourism Development, Avebury, England, pp.3-24.

Burns, P., 1999, Paradoxes in Planning: Tourism elitism or brutalism? Annals of Tourism Research,Vol.26(2), pp.329-348.

Butler, R., 1980, The concept of a tourism area cycle of evolution: implications for resources, Canadian Geographer, Vol. 24(1), pp.5-12.

Bywater, M., 1992, The European Tour Operator Industry, Economist Intelligence Unit, London.

Bywater, M., 1997, The European Agency Industry, Travel and Tourism Intelligence, London.

Calantone, R. J., Mazanec, J. A., 1991, Marketing management and tourism, Annals of Tourism Research, Vol.18(1), pp.101-119.

Chacko, H. E., 1997, Positioning a tourism destination to gain a competitive edge, Asia Pacific Journal of Tourism Research, Vol. 1(2), pp.69-75.

Chon, K. S., 1991, Tourism destination image modification process: marketing implications, Tourism Management, Vol.12(1),pp.68-72.

Chon, K. S., 1992, Self-image/destination image congruity, Annals of Tourism Research, Vol.19(2),pp.360-363.

Choy, D. J. L., 1992, Life cycle models for Pacific island destinations, Journal of Travel Research, Vol.30(3), pp.26-31.

Conlin, M., and Baum, T., 1995, (eds), Island Tourism: management, principles and practice, Wiley, London.

Cooper, C. P., 1989, Tourist product life cycle, in Witt, S.F. and Moutinho, L.(eds), Tourism marketing and management handbook, London: Prentice Hall, pp.577-580

Cooper, C., 1992, The life cycle concept and tourism, in Johnson, P.; Thomas, B., (eds), Choice and demand in tourism, London, UK; Mansell, pp.145-160.

Cooper, C., 1994, Tourism product life cycle, in Seaton, A., et al (eds) Tourism: The state of the art, J., Wiley, Chichester, pp.340-346.

Cooper, C., and Buhalis, D., 1992, Strategic management and marketing issues for SMTEs: A case study of the Greek Aegean Islands, in Teare, R., et al, (Eds), Projects in Hospitality Organisations, Cassell, London.

Cooper, C., and Jackson, S., 1989, Destination life cycle. The Isle of Man case study, Annals of Tourism Research, Vol.16(3), pp.377-398

Cooper, C., Fletcher, J., Gilbert, D., Shepherd, R., Wanhill, S., (eds), 1998, Tourism: Principles and Practices, $2^{\text {nd }}$ ed, Addison Wesley Longman, England.

Crouch, G. I., 1994, Promotion and demand in international tourism, Journal of Travel \& Tourism Marketing, Vol.3(3),pp.109-125.

Davidson, R., 1994, Business Travel, Pitman, London.

Davidson, R., and Maitland, R., 1997, Tourism destinations, Hodder \& Stoughton, London.

Douglas, N., 1997, Applying the life cycle model to Melanesia, Annals of Tourism Research, Vol.24(1), pp.1-22.

Edwards, A., 1993, Price Competitiveness of holiday destinations: Costs for European Travellers, Research Report, Economist Intelligence Unit, London.

Evans, M. R., Fox, J. B., Johnson, R. B., 1995, Identifying competitive strategies for successful tourism destination development, Journal of Hospitality \& Leisure Marketing, Vol. 3(1), pp.37-45.

Faulkner, B., 1997, A model for the evaluation of national tourism destination marketing programs, Journal of Travel Research, Vol.35(3), pp.23-32

Fayos-Sola, E., 1992, A strategic outlook for regional tourism policy: The White Paper on Valencian tourism, Tourism Management, No.13(1), pp.45-49.

Fayos-Sola, E., 1996, Tourism policy: a midsummer night's dream?, Tourism Management, Vol.17(6), pp.405-412

Formica, S., Uysal, M. 1996, The revitalization of Italy as a tourist destination, Tourism Management, Vol.17(5), pp.323-331

Garrod, G., Willis, K. G., 1992, The amenity value of woodland in Great Britain: a comparison of economic estimates, Environmental and Resource Economics, Vol.2(4), pp.415-434.

Gayle, D., and Goodrich, J., 1993, Tourism marketing and management in the Caribbean, Routledge. 
Getz, D. 1992,Tourism planning and destination life cycle, Annals of Tourism Research, Vol.19(4), pp.752-770

Gilbert, D., 1984, The need for countries to differentiate their tourist product and how to do so, Seminar papers: tourism managing for results, University of Surrey, Guildford.

Gilbert, D., 1990, Strategic marketing planning for national tourism, The Tourist Review, No.1, pp.18-27.

Gilbert, D., 1991, An examination of the consumer decision process relate to tourism, in Cooper, C., (Eds), Progress in Tourism, Recreation and Hospitality Management, Vol.3, Belhaven, London.

Gilbert, D., 1993, Consumer Behaviour and tourism demand, in Cooper, C., Fletcher, J., Gilbert, D., and Wanhill, S., (Eds), Tourism: Principles and Practice, Pitman Publishing, London, pp.20-31.

Goodall, 1988, How tourists choose their holidays: An analytical framework, in Goodall and Ashworth, (ed), Marketing in the tourism industry: The promotion of destination regions, Groom Helm, London.

Goodall, 1991, Understanding holiday choice, in Cooper, C., (Eds), Progress in Tourism, Recreation and Hospitality Management, Vol.3, Belhaven, London, pp.58-77.

Goodall, B., and Ashworth, G., (eds), 1988, Marketing in the tourism industry: The promotion of destination Regions, Groom Helms, London.

Gunn, C., 1994, Tourism Planning, Taylor and Francis, $3^{\text {rd }}$ ed, London.

Hawes, D. K., Taylor, D. T., Hampe, G. D., 1991,Destination marketing by state, Journal of Travel Research, Vol.30(1), pp.11-17.

Haywood, K. M., 1986, Can the tourist-area life cycle be made operational?, Tourism Management, Vol.7(3), pp.154-167

Heath, E., Wall, G., 1992, Marketing Tourism Destinations: A strategic Planning Approach, Wiley, New York.

Horner, S., and Swarbrooke, J., 1996, Marketing Tourism, Hospitality and Leisure in Europe, Thomson Business Press, London.

Hu, Y. Z., Ritchie, J. R. B., 1993, Measuring destination attractiveness: a contextual approach, Journal of Travel Research, Vol.32(2),pp.25-34.

Hughes, G., 1995, Authenticity in tourism, Annals of Tourism Research, Vol.22(4), pp.781-803.

Inskeep, E., 1991, Tourism Planning: An integrated and sustainable approach, Van Nostrand Reinhold: New York.

Inskeep, E., 1994, National and Regional Tourism Planning, Routledge, London.

Jamal, T., and Getz, D., 1996, Does strategic planning pay? Lessons for destinations from corporate planning experience, Progress in Tourism and Hospitality Research, Vol.2(1),pp.59-78.

Jenner, P., Smith, C., 1993, Tourism in the Mediterranean, Economist Intelligence Unit, London.

Johnston, B. R., Edwards, T., 1994, The commodification of mountaineering, Annals of Tourism Research, Vol. 21(3),pp.459-478.

Kent, P., 1991, Understanding holiday choices, in Sinclair and Stabler, M., (eds), The tourism industry: An International Analysis, CAB International, Oxford, pp. 165-185.

Khan, S. A., 1994, Tourism and a European strategy for the alpine environment, in Cater, E.; Lowman, G. (eds), Ecotourism: a sustainable option? John Wiley \& Sons, Chichester, UK, pp.103-110.

Kotler, P., Bowen, J., and Makens, J., 1996, Marketing for Hospitality and Tourism, Prentice Hall: UK.

Laarman, J. G., Gregersen, H. M., 1996, Pricing policy in nature-based tourism, Tourism Management, Vol.17(4), pp.247-254.

Law, C., 1993, Urban Tourism: Attracting visitors to large cities, Mansell, London.

Law, C., 1996, (ed), Tourism in major cities, Thomson Business Press, London.

Leiper, N., 1995, Tourism Management, RMIT Press, Melbourne.

Lockhart, D., and Drakakis-Smith, D., 1997, (eds) Island Tourism: Trends and Prospects, Pinter, London.

Mansfeld, Y., 1995, The "value stretch" model and its implementation in detecting tourists' classdifferentiated destination choice, Journal of Travel \& Tourism Marketing, Vol.4(3), pp.71-92.

March, R., 1994, Tourism marketing myopia, Tourism Management, Vol.15(6), pp.411-415.

Mayo E., and Jarvis, L., 1981, The psychology of leisure travel, CBI Publishing, Boston. 
Mazanec, J., 1989, Consumer behaviour in tourism, in Witt, S., and Moutinho, L., (ed), Tourism marketing and management handbook, Practice Hall, London, pp. 69-73.

Mazanec, J., 1997, (ed) International City tourism: Analysis and Strategy, Pinter, London.

Mazanec, J., and Zins, A., 1994, Tourist behaviour and the new European life style typology, in Theobold, W. (ed.), Global Tourism: The next decade, Oxford: Butterworth-Heinemann, pp.199-216.

McKercher, B., 1995, The destination-market matrix: a tourism market portfolio analysis model, Journal of Travel \& Tourism Marketing, Vol.4(2), pp.23-40.

McWilliams, E. G., Crompton, J. L., 1997, An expanded framework for measuring the effectiveness of destination advertising, Tourism Management, Vol.18(3),pp.127-137.

Meidan, A., 1995, Pricing, in Witt, S.F. and Moutinho, L.(eds), Tourism marketing and management handbook, Student Edition, London: Prentice Hall, pp.367-375.

Middleton, V., 1992, Marketing in Travel and Tourism, 2nd ed, Heinemann, London.

Middleton, V., and Hawkins, R., 1998, Sustainable tourism: a marketing perspective, ButterworthHeinemann, Oxford.

Morgan N., and Pritchard, A., 1998, Tourism Promotion and Power: Creating Images, creating identities, Wiley, Chichester.

Morgan, M., 1995, Homogeneous products: the future of established resorts, in Theobald, W. F, (ed), Global tourism: the next decade, Butterworth-Heinemann Oxford.

Moutinho, L., 1987, Consumer Behaviour in Tourism, European Journal of Marketing, Vol. 21(10), pp. $1-44$.

Murphy, P. E., Pritchard, M., 1997, Destination price-value perceptions: an examination of origin and seasonal influences, Journal of Travel Research, Vol.35(3), pp.16-22

O'Brien, K., 1996, The West European Leisure Travel Market: Forecasts for opportunities into the next century, Financial Times Newsletters and Management Reports, London.

O'Brien, K., 1998, The European Business Travel Market, Travel and Tourism Analyst, no.4, pp. 37-54.

Oppermann, M., 1996, Rural tourism in southern Germany, Annals of Tourism Research, Vol.23(1), pp.86-102.).

Page, S., 1994, Urban Tourism, Routledge, London.

Page, S., and Getz, D., 1997, (eds), The business of rural tourism: International perspectives, Thomson Business Press, London.

Palmer, A., Bejou, D., 1995, Tourism destination marketing alliances, Annals of Tourism Research, Vol.22(3), pp.616-629.

Pearce, D. G., 1997, Competitive destination analysis in Southeast Asia, Journal of Travel Research, Vol.35(4),pp.16-24.

Pearce, D., 1989, Tourist Development, Longman: Essex, UK.

Pigram, J., 1996, Best practice environmental management and the tourism industry, Progress in Tourism and Hospitality Research, Vol.2(3\&4),pp.261-271.

Poon, A., 1989, Competitive strategies for new tourism, in Cooper, C., (ed.), Progress in -Tourism Recreation and Hospitality Management, Vol.1, Belhaven Press, London, pp.91-102.

Poon, A., 1993, Tourism, technology and competitive strategies, CAB International, Oxford.

Porter, M., 1980, Competitive strategy: techniques for analysing industries and competitors, Free Press, New York.

Porter, M., 1985, Competitive advantage, Free Press, New York.

Ritchie, 1996, Beacons of light in an expanding universe: an assessment of the state-of-the-art in tourism marketing/marketing research, Journal of Travel \& Tourism Marketing, Vol.5(4), pp.49-84.

Ritchie, B., and Crouch, G., 1993, Competitiveness in international tourism: A framework for understanding and analysis, Annual Congress of the International Association of Scientific Experts in Tourism, Baliloche, Argentina.

Ryan, C. 1997, The tourist experience: A new Introduction, Cassell, London.

Ryan, C., 1991a, Recreational Tourism: A social Science Perspective, Routledge, London.

Ryan, C., 1991b, Tourism and marketing-A symbiotic relationship, Tourism Management, Vol.12(2), pp.101-111.

Sautter, E. T., and Leisen, B., 1999, Managing stakeholders: A tourism planning model, Annals of Tourism Research, Vol.26(2), pp.312-328. 
Schoenbachler, D. D., Benedetto, C. A. di, Gordon, G. L., Kaminski, P. F., 1995, Destination advertising: assessing effectiveness with the split-run technique, Journal of Travel \& Tourism Marketing, Vol. 4(2), pp.1-21.

Seaton, A., 1997, Destination Marketing, in Seaton, A., and Bennett, M.,(eds), marketing Tourism Products: Concepts, issues, cases, Thomson Business Press, London.

Sharpley, R., and Sharpley, J., 1997, Rural Tourism, Thomson Business Press, London.

Shaw, G., and Williams, A., 1997, (eds), The rise and fall of British Coastal resorts: cultural and economic perspectives, Mansell, London.

Silver, I., 1993, Marketing authenticity in Third World countries, Annals of Tourism Research, Vol.20(2), pp.302-318.

Sirakaya, E., McLellan, R. W., Uysal, M., 1996, Modeling vacation destination decisions: a behavioral approach, Journal of Travel \& Tourism Marketing, Vol. 5(1/2), pp.57-75.

Sofield, T. H. B., 1991, Sustainable ethnic tourism in the South Pacific: some principles, Journal of Tourism Studies, Vol.2(1), pp.56-72.

Swarbrooke, J., and Horner, S., 1999, Consumer behaviour in Tourism, Butterworth-Heinemann, Oxford

Thomas, J., 1992, Tourism and the environment: an exploration of the willingness to pay of the average visitor, Conference proceedings Tourism in Europe: the 1992 conference, 8-10 July 1992, Durham, UK.

Tooman, L. A., 1997, Applications of the life-cycle model in tourism, Annals of Tourism Research, Vol.24(1), pp.214-234

Towner, B., Newton, M., 1996, (ed), Tourism in Spain: Critical issues, Cab, Oxford.

Tribe, J., 1997, Corporate strategy for tourism. International Thomson Business Press, London.

Vlitos-Rowe, 1994, International business travel: a changing profile, Economist Intelligence Unit, London.

Weiermair, K., 1993, Innovation and innovatory behaviour in the tourist industry: growth strategies for accommodation establishments in alpine regions, Revue de Tourisme, Vol. 48(1), pp.14-22.

Wicks, B. E., Schuett, M. A. 1991, Examining the role of tourism promotion through the use of brochures, Tourism Management, Vol.12(4), pp.301-312.

Wicks, B. E., Schuett, M. A., 1993, Using travel brochures to target frequent travellers and 'bigspenders', Journal of Travel \& Tourism Marketing, Vol.2(2/3), pp.77-90.

Woodside, A. G., 1990, Measuring advertising effectiveness in destination marketing strategies, Journal of Travel Research, Vol.29(2), pp.3-8.

Woodside, A., and Lysonski, S., 1989, A general model of traveler destination choice, Journal of Travel Research, Vol. 27(4), pp. 8-14.

Yuksel, F., Bramwell, B., Yuksel, A., 1999, Stakeholder interviews and tourism planning at Pamukkale, Turkey, Tourism Management, Vol.20(3),pp.351-360. 